\title{
Groundwater Management for Small Islands and Spatial Patterns (Case Study of Banggai Kepulauan Regency)
}

\author{
Jaka Suryanta ${ }^{1}$, Turmudi ${ }^{1}$, Irmandi Nahib ${ }^{1, *}$ \\ ${ }^{1}$ Geospatial Information Agency (Badan Informasi Geospasial), Jalan Raya Jakarta - Bogor KM 46, \\ Cibinong, Indonesia \\ *Corresponding author. E-mail: Irmandi@gmail.com
}

\begin{abstract}
Banggai Kepulauan (Bangkep) Regency with an area of 21,988.56 km2, 30\% of its territory is land, namely Peleng Island and several small islands, while the other $70 \%$ is in the form of sea. A small portion of the region experiences drought during the dry season and its geological factors, but in the next few decades water shortages will likely be widespread. Based on geological data, most of the area is in the form of limestone, coral reefs and sandy clay deposits mixed with sand (tuff) so that the aquifer is secondary, the river water flow is not permanent. In Perda No. 1 of 2016 the spatial pattern allocates settlements in coastal areas while investment in oil palm plantations in catchment areas is possible to disrupt water balance. This study aims to determine groundwater reserves and their predicted use for domestic based on the spatial pattern of Banggai Kepulauan Regency. The method used is the analysis of water resources balance based on space patterns until 2032 . Groundwater reserves $(\Delta \mathrm{S})$ are calculated based on the amount of precipitation $(\mathrm{P})$ minus Evapotranspiration (Ep) and surface flow (Q). Predictions of domestic water use are calculated based on the number of population in the nth year with the approach "Pn $=$ Po $(1+\mathrm{r}) \mathrm{n}$. The results showed that until 2032 domestic water needs were still sufficient, where groundwater filling was 10,976,246 m3 / year while usage reached 4,010,494.02 $\mathrm{m} 3 /$ year. This condition can be achieved if the ideal population distribution is evenly distributed throughout the region, but the reality in the planned pattern of population distribution is concentrated in coastal areas. To maintain the continuity of groundwater sources, detailed distribution of population and catchment area and protection of springs need to be focused on spatial patterns. The types of plantation crops need to be reviewed due to regional conditions. Water saving and rainwater utilization through a shelter and processing system are strongly recommended.
\end{abstract}

Keywords: Groundwater, Banggai Islands, Spatial Patterns

\section{INTRODUCTION}

Banggai Kepulauan (Bangkep) is the development of Bangggai district which was established as an autonomous region based on Law Number 51 of 1999 consisting of 12 sub-districts and in 2013 a new Regency was formed, namely Banggai laut. The regency is dominated by maritime with a sea area of around $72.83 \%$ or $18,828.10 \mathrm{~km} 2$ while the land is $3,160.46 \mathrm{~km} 2$, especially the inhabited island of 113025 people in 2014 and in 2015 it rose to 114980 people (growth of $0.85 \%$ per year).

Experts formulate islands categorized as small if the area is less than $2000 \mathrm{~km} 2$ and width is less than $10 \mathrm{~km}$ [1] with a population of less than 200,000 people, while other definitions according to Beller at all 1990 are small categories if the area is less than or equal to $10,000 \mathrm{~km} 2$ with a population of less than 500,000. Referring to the definition, Peleng Island covering 2,406 $\mathrm{km}^{2}$ includes the category of approaching small islands with vulnerable ecosystems, but the spirit of development wants to advance and increase the prosperity of its population, so the management of this area is still realized as an autonomous region.

Through medium-term and long-term development programs, Spatial Planning becomes the government's reference in regulating the growth and utilization of the territory and natural resources that are owned. This new district has been quite advanced in terms of providing clean water facilities, where in 2013 most of the sub-districts had obtained clean water supply facilities managed by the PDAM. The amount of drinking water supplied by the PDAM to customers is $640,155 \mathrm{~m} 3$ with the number of customers recorded at 4,139 customers $(30 \%$ of the total population |), others using shallow groundwater.

Based on the PERDA of Banggai Kepulauan District No.1 Th 2016 concerning RT/RW 2016 - 
2036 specifically the spatial pattern, agricultural land is provided in the relatively small area of Tinangkung subdistrict, but the management has now granted oil palm plantation permits, with a permit of 10 thousand hectares more on the peling today. Then the question is what land will be converted into oil palm plantations, whether using conversion forest or HPT or sacrificing catchment areas. According to the space pattern, the allocation of land for settlements is quite extensive, located on the plain of the coast along the coast. What is interesting in this study is how the availability of groundwater for domestic until 2036, with concerns about the distribution of settlements around the coast with limited water, while production forests, or catchment areas will be utilized for oil palm. What is the current groundwater reserves and utilization for domestic and prediction until 2036.

Research purpose is to estimate groundwater reserves and predictions for domestic use based on space pattern trends until 2036.

\section{METHODS}

\subsection{Research Sites}

Bangkep Regency has main land areas, namely Peleng Island $(2,406 \mathrm{~km} 2)$ and several other islands including Banggai Island $\left(268 \mathrm{~km}^{2}\right)$, Bangkurung Island $\left(145 \mathrm{~km}^{2}\right)$, Bokan Islands Island $\left(84 \mathrm{~km}^{2}\right)$, Labobo Island $\left(80 \mathrm{~km}^{2}\right)$ and several islands smaller ones. with a position between $1^{\circ}, 06^{\prime}-2^{\circ}, 20^{\prime}$ LS and $122^{\circ}, 40$ '-124 13 'East Longitude, index Figure 1 below.

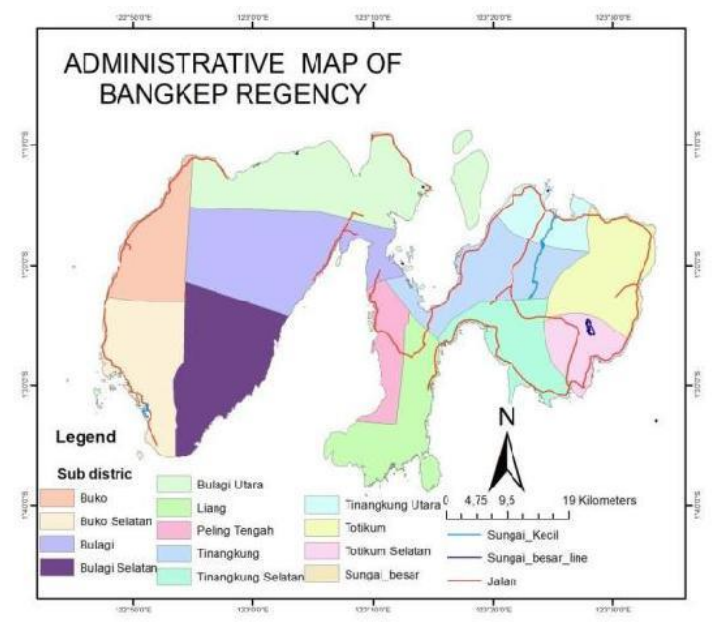

Figure 1. BangKep Regency, Central Sulawesi Prov

\subsection{Research Flow}

Small Island area management or watershed adheres to the principle of integration "one planning system in one Island and Watershed [2]. Particularly related components are hydrological, vegetation, environmental, socio-economic conditions and island with an island area of $2,406 \mathrm{~km}^{2}$ or around 4.3\%. As a comparison in Bualemo, Banggai district, which has a wider land area, only gives permits of around 3 thousand hectares, this is what is of public concern

institutions that regulate between sectors. In the framework of Bangkep District management, Figure 2 describes the related components and their functions, among others, the first upstream area is defined as a flow area limited to upstream where $>65 \%$ of the island's land surface generally has a slope of $>8 \%$. land use is land conservation and erosion control.Hydrologically, the upstream area usually forms the main area of recharge of rainfall for surface water and groundwater in the watershed [3]. utilization of river water that is managed to be able to provide benefits for social interests and the local economy, can be indicated from vegetation cover, availability of surface water and groundwater. The ability to channel water outside the watershed (interbasin transver) or internal watershed itself needs irrigation facilities and infrastructure, management of rivers, reservoirs or lakes with water balance indicators (Priyanto, B. 2011).

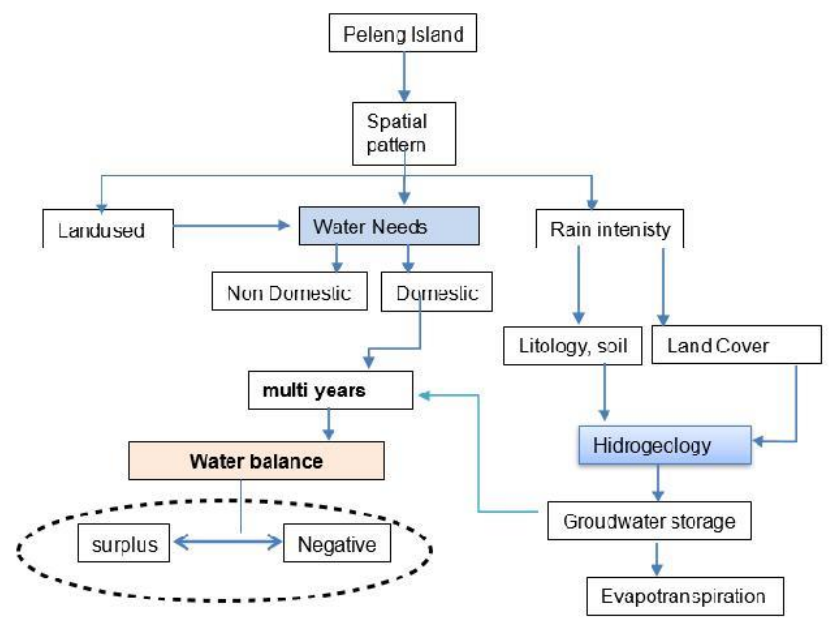

Figure 2. Describes the related components and their functions

\subsection{Groundwater Potential}

The potential of groundwater is calculated based on rainfall data (hydrometeorology) and hydrogeological conditions based on a hydrogeological map of a scale of 1: 250,000 Peleng island areas published by the Directorate of Geology and Environmental Management. According to [4], the water balance of a watershed or island can be calculated based on the formula approach as follows:

$$
\Delta \mathrm{S}=\mathrm{P}-\mathrm{EP}-\mathrm{Q}
$$

Where $\Delta \mathrm{S}$ is groundwater deposits:

$\begin{array}{ll}\mathrm{P} & =\text { Precipitation } \\ \mathrm{EP} & =\text { Evapotranspiration }\end{array}$ 
Q $=$ River discharge.

\subsection{Groundwater Utilization}

The people of the proudi district of the archipelago have partially utilized Pam water taken from several springs, while others use ground water which is only in the gap or secondary aquifer. Groundwater is formed in relatively flat areas and basins, so that many settlement plans utilize areas that are close to the coastline, in addition to the central island area being used as catchment areas. Domestic water needs are currently calculated based on the standard needs of the population, while the prediction of increasing future needs is based on population growth [5] with the following approaches:

$$
\mathrm{Pn}=\mathrm{Po}(1+\mathrm{r}) \mathrm{n}
$$

Information:

Pn $=$ number of population in year $n$

Po $=$ number of population in year 0 or base year $\mathrm{n}=$ number of years between 0 to $\mathrm{n}$ $\mathrm{r}=$ population growth rate per year (in\%)

The standard for domestic water needs refers to the PU workshop standards in Table 1, where domestic is defined as the water requirements used in private dwellings to meet daily needs such as; cooking, drinking, washing and other household needs.

Table 1. Determination of domestic Water Service Levels

\begin{tabular}{clll}
\hline No & Population number (soul) & Service Level (liters / person / day & Information \\
\hline 1 & $>1.000 .000$ & 120 & Medium urban \\
2 & $500.000-1.000 .000$ & 100 & Medium urban \\
3 & $100.000-500.000$ & 90 & Small urban \\
4 & $20.000-100.000$ & 80 & Small urban \\
5 & $10.000-20.000$ & 60 & Rural \\
6 & $<10.000$ & 30 & Rural
\end{tabular}

Source: [6]

\section{RESULTS AND DISCUSSION}

\subsection{Rain Potential}

Both shallow and deep ground water is the result of input of rain water in the form of infiltration and percolation for several decades recharge which is accommodated in aquifers. Shallow ground water can fluctuate [7] according to the season due to short-term filling according to the season. The ability of aquifers to store groundwater depends on the type of rock, some are good until the type that is difficult to store water depends on the level of permeability and transmission. Sand is an example of a good aquifer and in contrast clay and a combination of both of them with other materials. The average rainfall in Bangkep Regency is in the moderate category, which is between $800 \mathrm{~mm} /$ year to $2000 \mathrm{~mm} \mathrm{/} \mathrm{year}$ depending on the altitude and geographical position of the region. Figure 3 below shows the distribution pattern of rain potential in the form of an isohyet map.

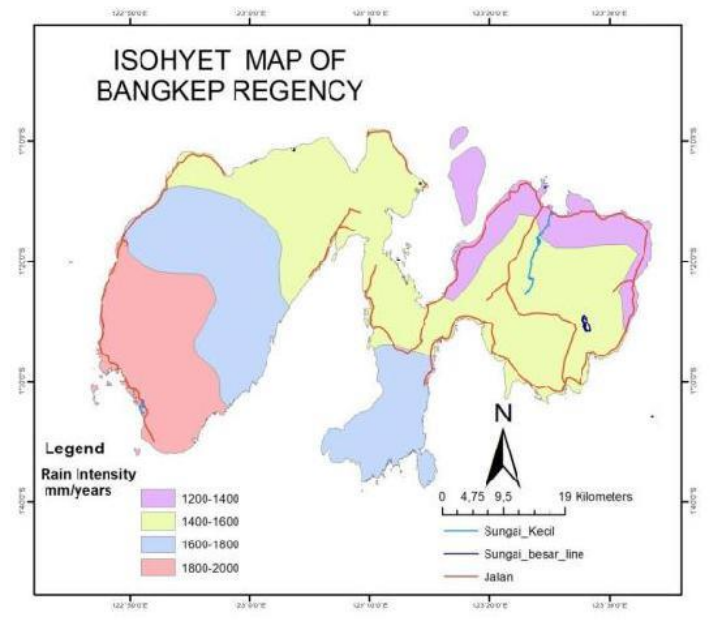

Figure 3. Isohyet map of Bangkep Regency

From the monthly rainfall distribution, it shows that rainy days occur a lot in March April and June to August, so that in a year the rainy season occurs twice, while the Isohyet map shows that the western region is wetter and the rainfall is decreasing. Figure 4 shows the rainfall patterns in Bangkep district which will affect both shallow groundwater fluctuations and seasonal cropping patterns. 


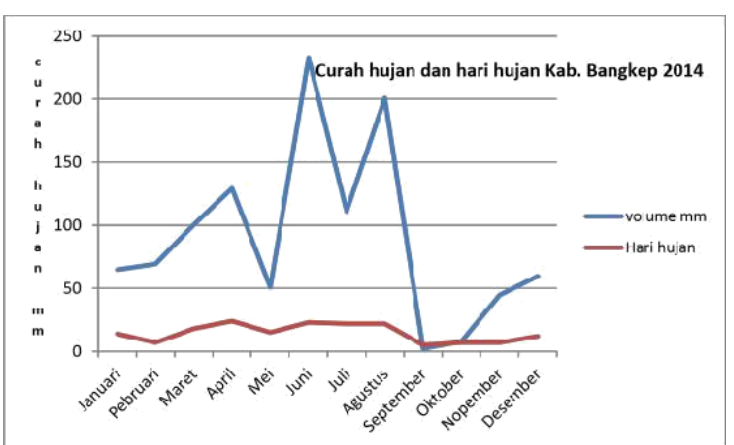

Figure 4. Shows the rainfall patterns in Bangkep

\subsection{Quantity of Groundwater}

According to Seyhan groundwater filling $(\Delta S)$ is determined by the potential of rain $\mathrm{P}$, EP consumption and area of the aquifer capable of absorbing and surface water discharge influenced by vegetation of the rock cover. From the data on land use of vegetation types and land of this region and considering the lithology conditions according to the geological map, Figure 5., the less wellformed aquifers can be observed also from the least groundwater basin The next consequence is that the rivers are also not formed permanently where the dry season is immediately dry.

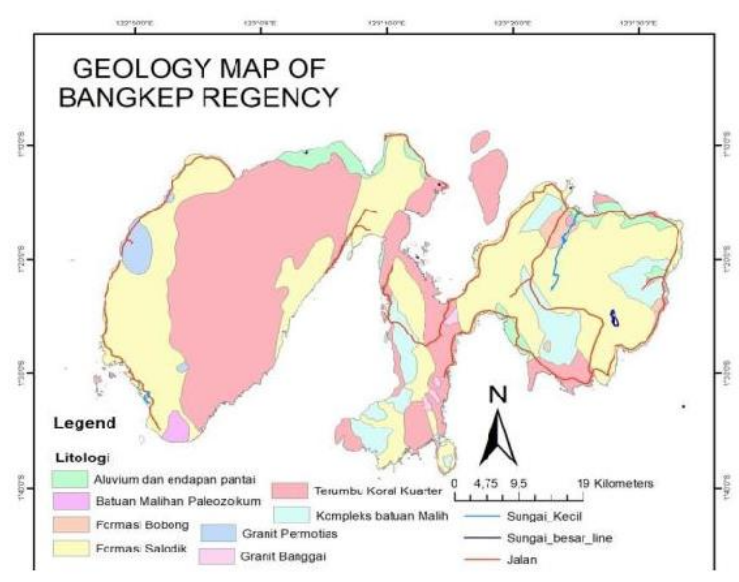

Figure 5. Geological map of Bangkep Regency

Based on the rainfall data and others it is estimated that the average evaporation runoff and groundwater filling are fully presented in Table 2 . The data shows estimates of annual groundwater recharge in the form of infiltration and percolation of 10.09 million $\mathrm{m} 3$ per year for peleng islands which are approximately $2,406 \mathrm{~km} 2$.

Table 2. Estimated annual groundwater recharge

\begin{tabular}{|c|c|c|c|c|c|c|}
\hline Litologi & Luas & $\mathrm{CH}$ & Pot. CH & Evapotranpirasi & Run Off & $\begin{array}{c}\text { Infiltrasi dan } \\
\text { perkolasi } \\
\end{array}$ \\
\hline- & $\mathrm{km}^{2}$ & $\mathrm{~mm}^{3} / \mathrm{Th}$ & $10^{3} \mathrm{~m}^{3} / \mathrm{Th}$ & $10^{3} \mathrm{~m}^{3} / \mathrm{Th}$ & $\begin{array}{c}10^{3} \\
\mathrm{~m}^{3} / \mathrm{Th}\end{array}$ & $10^{3} \mathrm{~m}^{3} / \mathrm{th}$ \\
\hline Gamping koral & 1.040 & 1.600 & 1.664 & 665 & 582 & 416 \\
\hline Granit turmalin & 885 & 900 & 796 & 319 & 239 & 239 \\
\hline Granit diorit & 621 & 800 & 497 & 199 & 149 & 149 \\
\hline $\begin{array}{l}\text { Konglomerat } \\
\text { breksi }\end{array}$ & 26 & 1.200 & 31 & 12 & 9 & 9 \\
\hline Skis, mika & 128 & 1.800 & 230 & 92 & 69 & 69 \\
\hline Skis, genet & 76 & 1.000 & 76 & 31 & 23 & 23 \\
\hline $\begin{array}{c}\text { Napal, gamping } \\
\text { pasiran }\end{array}$ & 235 & 1.900 & 446 & 178 & 134 & 134 \\
\hline $\begin{array}{l}\text { Lumpur, } \\
\text { lempung }\end{array}$ & 246 & 700 & 172 & 69 & 52 & 52 \\
\hline & 2.406 & & 30.912 & 10.565 & 10.257 & 10.090 \\
\hline
\end{tabular}

\subsection{Spatial Pattern}

The spatial pattern is the direction of the government in utilizing the land of a region, one of which is direction for current and future settlement plans until the year specified such as Figure 6, namely the Bangkep district 2016 until 2036 


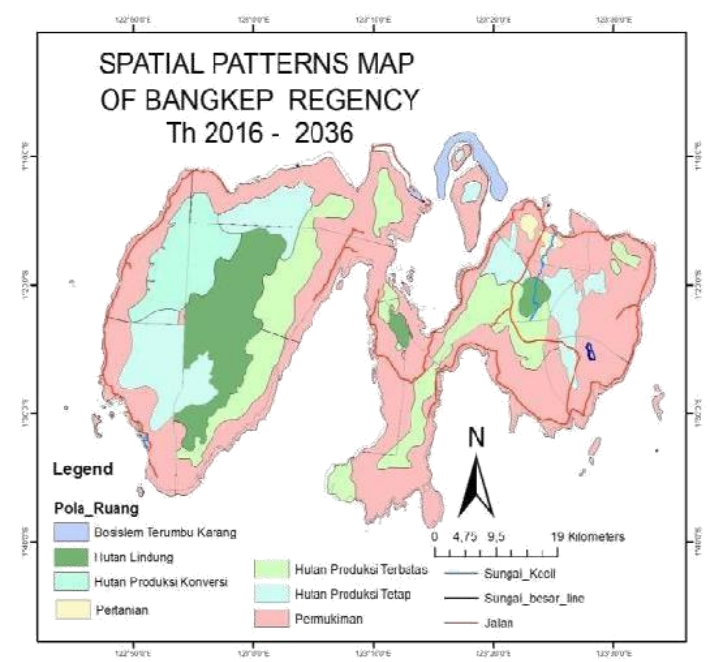

Figure 6. Spatial Pattern of Bangkep Regency $2016-2036$

In planning the spatial pattern, the government allocates land for protected forest $10.27 \%, 35.07 \%$ production forest is quite ideal, on the other hand settlements reach $52.44 \%$, which is quite large, what is all the distribution along the coast, this needs to be detailed when make plans more operational (large scale) where each residential block is allocated a catchment facility. The groundwater system in this coastal area is very susceptible to intrusion if in the future the extraction of groundwater in this area is excessive [8] or not measured according to its potential because of the secondary aquifer conditions according to the explanation above.

\subsection{Population and Water Needs}

The population in 2013 in Bangkep Regency was 113,025 people and in 2015 it rose to 114980 people (growth of $0.85 \%$ per year) according to BPS data. Based on this growth rate, the population in the next few years can be predicted according to equation 2 above, population calculations and water needs can be presented as Table 3 . The standard needs used are according to Ditjen Cipta Karya, for small cities with a population of close to one hundred thousand 801 / person / day. Table 3 . Population growth and domestic water needs until 2036.

Table 3. Population growth and domestic water needs until 2036

\begin{tabular}{|c|c|c|c|c|c|c|c|c|c|c|c|c|}
\hline Th & 2015 & 2017 & 2019 & 2021 & 2023 & 2025 & 2027 & 2029 & 2031 & 2033 & 2035 & 2036 \\
\hline penduduk & 114.980 & 116.943 & 118.939 & 120.970 & 123.03 & 5125.135 & 127.272 & 129.445 & 131.654 & 133.902 & 136.188 & 137.346 \\
\hline $\begin{array}{l}\text { Keb. Ail } \\
\text { m^3/hr }^{\wedge}\end{array}$ & $9.198,4$ & $9.355,4$ & $9.515,1$ & 9.776 & 9.842 & $10.010,8$ & $10.181,7$ & $10.355,6$ & $0.532,41$ & $0.712,2$ & $10.895,0$ & $10.987,7$ \\
\hline
\end{tabular}

Groundwater recharge is assumed to be stable as long as there are no changes in land use and extreme climate changes. However, in reality, water catches will certainly decrease due to land use factors, so that water use will always increase and filling will decrease, therefore sustainable water management is needed because there will be an imbalance that can cause groundwater degradation. Another factor that needs to be considered is that the development of this regional tourism is very advanced, with the indication that the hotel occupancy rate (TPK) is up, in March 2017 rose by 44.50 percent, up 5.45 percentage points by 39.05 percent and most hotels will grow in coastal areas.

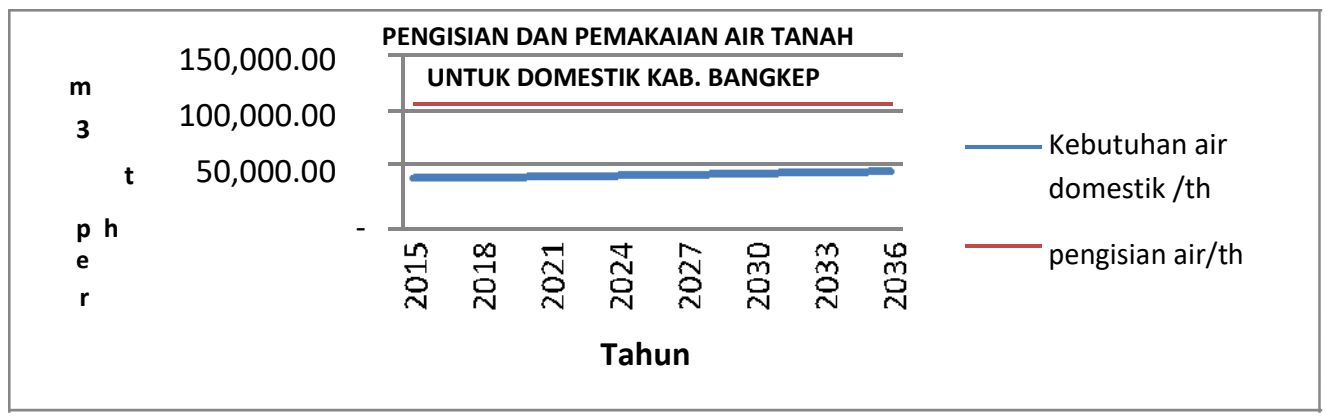

Figure 7. Recharge groundwater and domestic water needs 


\section{DISCUSSION}

Peleng Island as the main land area of Bangkep Regency with an area of $2,406 \mathrm{~km}^{2}$ in 2015 with a population of 114980 people or with a density of 0.5 people / ha including very rare categories. But the island's population is concentrated in coastal areas with an increase of $0.85 \%$ per year predicted in 2036 to grow to 137,345 . Most of the population (70\%) use shallow groundwater to meet domestic needs, only $4,139(30 \%)$ are recorded using PAM water which is also taken from springs. The domestic water demand is increasing and it is estimated that in 2036 it will be $4,010,494.02 \mathrm{~m} \wedge 3 /$ year while the filling of rainwater into the aquifer is 10,976,246 M3

/ year so that the needs are still very sufficient. However, related to changes in land use, filling in aquifers tends to decrease plus the issue of permits for oil palm plantations that will compete to absorb sufficient water needs. Furthermore, management of land use must be a serious concern of the local government, especially in distributing the distribution of the population, which needs to be balanced with water services in piping, so that there is not much use of shallow ground water because this water has a short cycle associated with aquifer conditions.

The application of RO technology on the Island can be applied but in very crucial places, namely to meet the standard drinking water needs of 8 liters / soul / day. Other opportunities for the community to consume rain water so that in the rainy season do not use RO water, which is generally a burden on the government in operating the water treatment unit. On the island of Pelang, clean water management has begun to be implemented, namely by piping clean water, but it needs to be increased from $30 \%$ gradually to $80 \%$ considering the shallow groundwater and aquifers there are secondary. To overcome the problem of clean water needs on Pelang Island, the principle of sustainable water management should be carried out, including:

1. Appropriate technology namely clean water management technology that is applied based on the nature and function of the island's natural environment, can be applied and in accordance with the built environment and social environment. The technology used can be carried out by the community and provides benefits in accordance with the objectives of clean water management.

2. Managing the quantity of clean water, namely to increase the relative amount of clean water to the population. Includes: a). Rainwater harvesting, which is catching rainwater from the roof and stored in a tank / reservoir. Rainwater shelters must be owned by every house and in it can be given treatment so that the water entering the tank is not polluted by pollutants in the environment and can add minerals needed by humans. b). Spatial planning and overcoming the problem of population density, reforesting the coastal land in accordance with the island environment. c). Savings in utilizing clean water,

3. The management of clean water quality aims to prevent pollutants from entering clean water, either in the reservoir or stored as shallow groundwater. The management of clean water quality can be done by: improving sanitation and controlling groundwater extraction. Things that affect the success of sustainable clean water management are: a). The concept of sustainable clean water management by adjusting the nature of natural environment, built environment and social environment. b). There is coordination between related agencies in conducting clean water management activities. c). Involve the community in sustainable management of clean water. d). Information dissemination of clean water continuously so that sustainable management of clean water can be one part of the activities of the life of Peleng Island residents.

\section{CONCLUSION}

In the groundwater aquifer in Bangkep district there are groundwater reserves of 10,976,246 m3 / year based on water balance calculations, naturally the rock types only support the formation of secondary aquifers. The spatial pattern until 2036 the government still considers $35 \%$ upstream water catchment area in the form of production forest and $10 \%$ of protected forest. The allocation of land for settlements covering 52\% along the coastal area prepared until 2036 will require domestic water needs to reach 4,010,494.02 $\mathrm{m} 3$ / year. Based on the reserve and demand for ground water, the population growth of Banggai Regency will still be fulfilled but it is necessary to consider the availability of additional recharge in residential blocks and public facilities, to maintain groundwater preservation in the coastal areas.

\section{ACKNOWWEDGMENT}

The author would like to thank the Center for Geospatial Information PPKS for the availability of spatial data used in the analysis. To the friends of researchers who have given input and suggestions, as well as the Committee of the ICMACES Seminar in 2019 University of Lampung, which has accommodated the implementation of the seminar to compile writing in a scientific proceeding. 


\section{REFERENCES}

[1] UNISCO IHP 1993 [1]

[2] Taufik, M., Suprapto, dan H. Widiyono. 2010. Uji daya hasil pendahuluan jagung hibrida di lahan ultisol dengan input rendah. Akta Agrosia 13(1):70-76.

[3] Razak, A., \& Suprihardjo, R. (2013). Pengembangan Kawasan Pariwisata Terpadu Di Kepulauan Seribu. Jurnal Teknik Its, 2(1), C14-C19.

[4] Seyhan, Ersin., 1977. Dasar-dasar Hidrologi.Gadjah Mada Universiy Press. Yogyakarta.
[5] C. D. Soemarto, 1999, Hidrologi Teknik, Penerbit Erlangga, Jakarta.

[6] Ditjen Cipta Karya. 2000. Kriteria Perencanaan Ditjen Cipta Karya Dinas PU Tahun 2000. Ditjen Cipta Karya : Dinas Pekerjaan Umum. Jakarta.

[7] Delinom, R. M., \& Lubis, R. F. 2005. Airtanah Di Pesisir Dan Pulau-Pulau Kecil.

[8] Herlambang, A., \& Indriatmoko, R. H. (2011). Pengelolaan Air Tanah Dan Intrusi Air Laut. Jurnal Air Indonesia, 1(2). 